\title{
Exploring on the Construction of "Learning Community" Classroom of Computer Language Course
}

\author{
Yuanyuan Zhang $^{1, a}$ and Hui Jiang ${ }^{1, b}$ \\ ${ }^{1}$ School of Management Science and Engineering, Shandong Institute of Business and \\ Technology,264005 Yantai, China \\ afrank_zyy@sohu.com, ${ }^{b}$ helenjianghui@hotmail.com
}

Keywords: Learning community; Teaching model; Computer language course; Questionnaire; Satisfaction degree

\begin{abstract}
Learning community" of classroom is a new teaching model. It is designed on the basis of constructivism conception. There are a lot of achievements about the content of "learning community",but few about the actual effect. Therefore, it is necessary to use scientific method to analyze actual effect of the "learning community" .This paper designed the questionnaire according to SERVQUAL model. The questionnaire mainly includes this several aspects:: organization management of classroom teaching, the design of teaching content,the use of teaching methods and skills, and the acceptance of student etc. Statistical analysis was conducted to this new teaching model evaluation of students. The experiment result has indicated that the "learning community" teaching mode of computer language course could promote students "learning" and improve the students' satisfaction degree. This also proves the feasibility and effectiveness of the quality of higher education management theory to evaluate the teaching method of the computer language Java and other courses.
\end{abstract}

\section{Introduction}

"Learning community" of classroom is a new teaching model. It is designed on the basis of constructivism conception[1]. There are a lot of achievements about the content of "learning community",but few about the actual effect. Therefore, it is necessary to use scientific method to analyze actual effect of the "learning community". Shandong Institute of Business and Technology pay great attention to teaching reform. The author of this article actively practice the "learning community" teaching mode during teaching "Java program design" course construction.

\section{The Connotation and Characteristic of "learning community"}

In 1995, Boyer put forward the concept of "learning community" in the article "basic school: learning community". It is a special learning environment composed of learners and facilitators(including teachers, experts, counselors and parents) with the help of certain learning carrier[2].It is a sharing and cooperative organization. In this group, people have common expectations, purpose and interests; these common mental factors bind them together. During learning process, Learning community encourages learners to share information and their own opinion, to develop cooperation activities with their partners including to show knowledge, discuss and shoulder the responsibility. The members of learning community depend on each other, treat each other as their equals and pursue the maximized collective interests. Learners interact with others, mutual communicate and cooperate with each other. So they can reach consensus, sharing and common progress to achieve the teaching benefits teachers as well as students, and common development. In the process of constructing classroom learning community, teacher's responsibility is not only to tell a good lesson, but also to maximize each student's learning rights, make students try their best to bring their subjective initiative. "Learning community" has four characteristics.

Integrity. Each elements of a learning community as inseparable of the system, is a complete and orderly entirety. Community members have individual consciousness, can realize that they are 
learning in a community, also can feel the community's value and meaning to themselves[3]. Members believe themselves as part of the system, then there are trust and exchange between tutors and learners, between learners and learners. The common goal is to focus the discrete states in study together, to achieve a better result than in which tutors only teach and learners only passive learn[4].

Interactive. In the learning community, the realization of the teaching process is mainly through the interaction between teacher and his students, and the interaction between students and students, and between students and teaching content to complete[5,6]. By creating a democratic and harmonious and equitable atmosphere, the learning community make members freely exchange their views and ideas, cooperate with each other. This is no longer a simple transmission of information, but also a process of deeply understanding, processing and absorbing information. Each student is willing to share his insights with others, to accept the influence of others, to rich and expand his knowledge and improve his sense of self-efficacy in learning and problem-solving activities. In this process, the subjectivity, autonomy, initiative and independence of the student can be fully developed.

Normative. No rules no standards. The learning community also need to develop some norms and criteria to supervise the development of learners and the community. Positive, healthy, fair and equitable standards not only are the foundation of a cohesive learning community, but also can protect communities for sustainable development. The same learning objectives, similar values and norms, are the "glue" of a learning community, which regulate the behavior of members in the community, inspire and unite everyone's interest and passion for learning.

Flexibility in identity transformation. That is mean that, the identity of the participants can be reconstructed in the learning community. Anyone can contact with others in several different identities in a specific identity or role. The openness of exchanges can make each individual have the widest possible participation in the learning activities[7,8]. By building and experience a different identity, students can deal with different learning problems, learn from experience different roles in different learning. By changing identity, members in the learning community can share their knowledge, experience the intersection of ideology and emotional satisfaction, and improve their skills of coordination, cooperation, and communication.

\section{Research Methods}

In order to test the real effect of "learning community" to students, a questionnaire was designed according to SERVQUAL model[9,10]. It mainly includes this several aspects, such as organizational management of class teaching, the design of teaching content, the use of teaching methods and skills, and the acceptance of student etc. There ate 5 first class indexes and the second index of 20. Statistical analysis was conducted to this new teaching model evaluation of students. The experiment result has indicated that the " learning community" teaching mode of computer language course could promote students "learning" and improve the students' satisfaction degree. This also proves the feasibility and effectiveness of the quality of higher education management theory to evaluate the teaching method of the computer language Java and other courses. The primary elements of questionnaire is listed in table 1.

Table 1 Questionnaire of the safisfaction degree about learning community teaching model

\begin{tabular}{|c|c|c|}
\hline First-class indexes & Second-class indexes & $\begin{array}{l}\text { degree } \\
\text { satisfaction }\end{array}$ \\
\hline $\begin{array}{l}\text { organizational } \\
\text { management }\end{array}$ & $\begin{array}{l}\text { (i) maintenance of classroom order } \\
\text { (ii)push on group-cooperative } \\
\text { learning; } \\
\text { (iii) Participation of students; } \\
\text { (iv) The degree of democracy }\end{array}$ & $\begin{array}{l}\text { A. very satisfied } \\
\text { B. satisfactory } \\
\text { C. Normal very } \\
\text { D. unsatisfactory } \\
\text { E. } \quad \text { ve }\end{array}$ \\
\hline teaching content & contents & dissatisfied \\
\hline
\end{tabular}




\begin{tabular}{|l|l|}
\hline & $\begin{array}{l}\text { extensive information } \\
\text { (ii) the new achievements and new } \\
\text { knowledge of discipline; } \\
\text { (iii) open-ended; } \\
\text { (iv) practicality }\end{array}$ \\
\hline $\begin{array}{l}\text { teaching methods and } \\
\text { skills }\end{array}$ & $\begin{array}{l}\text { (i) various of teaching methods } \\
\text { (ii) role Exchange; } \\
\text { (iii) many kinds of communication } \\
\text { platform; and } \\
\text { (iv) Class discussion and } \\
\text { demonstration }\end{array}$ \\
\hline $\begin{array}{l}\text { the acceptance of } \\
\text { student }\end{array}$ & $\begin{array}{l}\text { (i) Interested in this course; } \\
\text { (ii) Contribute to the understanding of } \\
\text { basic concept; } \\
\text { (iii) improved programming ability; } \\
\text { (iv) improve the development ability } \\
\text { in software. }\end{array}$ \\
\hline
\end{tabular}

Based on the "Java" course curriculum characteristics, we choose the two natural classes of information management specialty of 2010 year. The two classes were divided into 2 groups: experimental group and control group. In order to compare the change of student satisfaction before and after the application of "learning community" teaching mode ,two surveys were conducted. When course began, the first survey occurred in February 2010. The second survey performed in June 2010 at the end of the course .

In the first questionnaire, 56 students were investigated and 53 questionnaires were valid in experimental group, the effective rate of the questionnaire was 94.6\%; 58 students were investigated and 55 questionnaires were valid in control group, the effective rate of the questionnaire was $94.8 \%$; in the second questionnaire, 56 students were investigated and 54 questionnaires were valid in experimental group, the effective rate of the questionnaire was 96.4\%; 58 students were investigated and 52 questionnaires were valid in control group, the effective rate of the questionnaire was $89.7 \%$.The collected data were statistical analyzed Using SPSS17.0. There are significant differences between the two collected data after the inspection. then has a significant influence the use of learning community teaching model on students' learning course satisfaction. This can show that significant influence on students' learning course satisfaction in the use of learning community teaching model.

\section{Conclusion}

Based on the previous theoretical study, the basic internal logic was formed in the study. Namely the students' satisfaction degree raised because the teacher constructed the "learning community". The results also proved this assumption.

Organizational management of class teaching. The results of data analysis show that the identity degree of organizational management significant raise. Before implementation of "learning community ", the identity degree is 3.51 . This value increase to 3.75 in the second survy. $\mathrm{P}$ is 0.017 and significance level is Achieved .The results are showed in table 2.

In the control group, the approval degree of teaching organizational management increased by 0.05. But the increase is not obvious comparing the added value of experimental group. The added value of control group do not associate with the implementation of "learning community ". 
Table 2 students' satisfaction degree of organizational management

\begin{tabular}{|c|c|c|c|c|c|c|c|}
\hline index & group & time & Count & average & average & Deviation & $\mathrm{P}$ value \\
\hline & & & $\begin{array}{c}\text { of } \\
\text { student }\end{array}$ & & deviation & $\begin{array}{l}\text { between two } \\
\text { groups }\end{array}$ & \\
\hline \multirow{4}{*}{$\begin{array}{c}\text { satisfaction } \\
\text { degree }\end{array}$} & \multirow{2}{*}{$\begin{array}{l}\text { experimental } \\
\text { group }\end{array}$} & Second & 53 & 3.75 & \multirow{2}{*}{0.24} & \multirow{4}{*}{0.19} & \multirow{2}{*}{0.017} \\
\hline & & First & 55 & 3.51 & & & \\
\hline & \multirow{2}{*}{$\begin{array}{l}\text { Control } \\
\text { group }\end{array}$} & second & 54 & 3.31 & \multirow{2}{*}{0.05} & & \multirow{2}{*}{0.135} \\
\hline & & First & 52 & 3.26 & & & \\
\hline
\end{tabular}

Teaching content. The value of satisfaction degree of experimental group increase 1.24. But the increase of control is not obvious comparing the added value of experimental group. Through the above experimental group compared with control group, the conclusion was drawn. The satisfaction degree of student in experimental group has been improved according to the implementation of "learning community". The results are showed in table 3.

Table 3 students' satisfaction degree of organizational teaching content

\begin{tabular}{|l|l|l|l|l|l|l|l|}
\hline index & group & time & $\begin{array}{l}\text { Count } \\
\text { of } \\
\text { student }\end{array}$ & average & $\begin{array}{l}\text { average } \\
\text { deviation }\end{array}$ & $\begin{array}{l}\text { Deviation } \\
\text { between two } \\
\text { groups }\end{array}$ & P value \\
\cline { 1 - 5 } $\begin{array}{l}\text { satisfaction } \\
\text { degree }\end{array}$ & $\begin{array}{l}\text { experimental } \\
\text { group }\end{array}$ & Second & 53 & 3.61 & 1.24 & 0.91 & 0.01 \\
\cline { 2 - 5 } & $\begin{array}{l}\text { Control } \\
\text { group }\end{array}$ & First & 55 & 2.37 & & \\
\cline { 2 - 5 } & Second & 54 & 3.11 & 0.33 & & 0.028 \\
\hline
\end{tabular}

Teaching methods and skills. The results of data analysis show that the identity degree of teaching methods significant raise. The identity degree of experimental group is 3.55 . The identity degree of control group is 2.11 . $\mathrm{P}$ is 0.015 and significance level is Achieved .The results are showed in table 4. The satisfaction degree of student in experimental group has been improved according to the implementation of "learning community".

Table 4 students' satisfaction degree of organizational teaching methods

\begin{tabular}{|c|c|c|c|c|c|}
\hline index & group & $\begin{array}{c}\text { Count of } \\
\text { student }\end{array}$ & average & $\begin{array}{c}\text { average } \\
\text { deviation }\end{array}$ & P value \\
\hline \multirow{2}{*}{$\begin{array}{c}\text { satisfaction } \\
\text { degree }\end{array}$} & $\begin{array}{c}\text { experimental } \\
\text { group }\end{array}$ & 55 & 3.55 & \multirow{2}{*}{1.43} & 0.012 \\
\cline { 2 - 4 } & Control group & 52 & 2.12 & \\
\hline
\end{tabular}

Acceptance of student. The results of data analysis show that the identity degree of acceptance of student raise. Students accept and love the new teaching model. The identity degree of experimental group is 3.90. The identity degree of control group is 3.24. Difference between the two groups of data is obvious. The results are showed in table 5.

Table 5 students' satisfaction degree of acceptance

\begin{tabular}{|c|c|c|c|c|c|}
\hline index & group & $\begin{array}{c}\text { Count of } \\
\text { student }\end{array}$ & average & $\begin{array}{c}\text { average } \\
\text { deviation }\end{array}$ & P value \\
\hline \multirow{2}{*}{$\begin{array}{c}\text { satisfaction } \\
\text { degree }\end{array}$} & experimental group & 55 & 4.01 & 0.45 & 0.014 \\
\cline { 2 - 4 } & Control group & 52 & 3.56 & 0.45 \\
\hline
\end{tabular}




\section{Acknowledgement}

This work is supported by the School of Management Science and Engineering teaching reform project(11688JXYJ2014003), Shandong Province humanities and social Sciences project (J13WG62)

\section{references}

[1] Staers A J, Becoming a professional educator in an urban school - university partnership: A case study analysis of preservice teacher learning, Teacher Education Quarterly, 2(2010) p.45.

[2] H.J.Pan and W.T Chen: New Horizons in Large Class Teaching: Learning Community Construction and Teaching Method Reform (Jiangsu University press,China, 2012,p.124). (In Chinese)

[3] John Retallick and Barry Cochlin. Learning Community in Education: Issues, Strategies and Contexts( Routledge, 1999).

[4] X.R. LIU: Theory and Practice of Education.vol.34(2014) No.7, p.56. (In Chinese)

[5] W.M. Yang: Higher Education Exploration, (2013) No.4, p.17. (In Chinese)

[6] T.X. Zuo.Teachers ' challenge: quiet class teaching reform(East China Normal University Press,2012,p.156). (In Chinese)

[7] B.X. Long and Y.D. She: educational research,6(2014),p.122. (In Chinese)

[8] C.Zh.Hong: Study on Higher education service quality and student satisfaction(MS., Xiamen University, China 2009 ), p.7. (In Chinese)

[9] P.N. Wen and G.Y. Jia: Theory and Practice of Education,vol.43(2002)No.5, p.17. (In Chinese)

[10] Ch.J. Shi, Y.Ch. Liu: educational research., (2013) No.6, p.150. (In Chinese) 